\title{
PENGARUH PELARUT CAMPUR ETIL ASETAT DAN N-HEKSAN TERHADAP RENDEMEN DAN GOLONGAN SENYAWA EKSTRAK BIJI ALPUKAT
}

\section{EFFECT OF MIXING ETHYL ASETAT AND N-HECTAN AGAINST CHEMICAL COMPOUNDS AND RENDEMEN AVOCADO SEEDS EXTRACT}

\author{
Nadya Syafa'ah ${ }^{1}$, Rani Rubiyanti ${ }^{2^{\star}}$, Nur Aji ${ }^{3}$ \\ ${ }_{1,2,3}$ Poltekkes Kemenkes Tasikmalaya, Indonesia. \\ email: ${ }^{1}$ nadyasyafaah15@gmail.com, ${ }^{2 *}$ rani.rubiyanti@yahoo.co.id, ${ }^{3}$ nuraji090689@gmail.com
}

\begin{abstract}
ABSTRAK
Tanaman alpukat (Persea americana Mill.) tumbuh di wilayah tropis dan subtropis salah satunya di Indonesia yang diproduksi mencapai 3,631,476 kuintal. Alpukat mempunyai khasiat yang dapat mengatasi penyakit seperti monorrhagia, hipertensi, sakit perut, bronkitis, diare dan diabetes. Penelitian ini bertujuan untuk mengetahui perbandingan pelarut yang baik dalam persentase bobot rendemen biji alpukat dan mengetahui golongan senyawa kimia pada simplisia biji alpukat (Persea americana Mill.). Metode penelitian ini dilakukan menggunakan campuran pelarut etil asetat dan n-heksan dengan perbandingan $1: 9 ; 3: 7 ; 5: 5 ; 7: 3$ dan 9:1 terhadap $10 \mathrm{~g}$ biji alpukat dengan maserasi. Ekstrak cair yang diperoleh diuapkan sampai diperoleh ekstrak kental, lalu dilakukan perhitungan rendemen dan diidentifikasi golongan senyawa kimianya. Hasil rendemen dengan variasi pelarut etil asetat : $n$-heksan sesuai dengan perbandingan di atas berturut-turut dengan dua kali perlakuan yang sama, masingmasing menunjukkan hasil rendemen rata-rata berbeda yaitu $0,804 \% ; 1,444 \%$; $2,442 \% ; 3,600 \%$ dan 6,267\%. Hasil penapisan fitokimia ekstrak biji alpukat (Persea americana Mill.) positif mengandung senyawa kimia golongan alkaloid dan flavonoid. Perbandingan jumlah pelarut etil asetat: $n$-heksan berpengaruh terhadap jumlah rendemen.
\end{abstract}

Kata Kunci: biji alpukat, metode maserasi, pelarut campur.

\begin{abstract}
Avocado (Persea americana Mill.) grows in tropical and sub-tropical regions, one of them in Indonesia reaching 3,631,476 quintals. Avocado has properties that can overcome diseases such as monorrhagia, hypertension, abdominal pain, bronchitis, diarrhea and diabetes. This study aims to determine the ratio of good solvents in the percentage of yield weight of avocado seed and find out the chemical compounds in avocado seeds (Persea americana Mill.). This research was carried out using a mixture of ethyl acetate and $n$-hexane with a ratio of $1: 9 ; 3: 7 ; 5: 5 ; 7: 3$ and $9: 1$ against $10 \mathrm{~g}$ of avocado seeds with maceration. The liquid extract obtained was evaporated until a thick extract was obtained, then the rendement was calculated and the chemical compound group was identified. The yield with the variation of
\end{abstract}


ethyl acetate: n-hexane $1: 9 ; 3: 7 ; 5: 5 ; 7: 3$ and $9: 1$ respectively with the same treatment twice, each of which shows the results of the different yields of the average of $0,804 \% ; 1,444 \%$; $2,442 \% ; 3,600 \%$ and $6,267 \%$. Phytochemical screening results of avocado seed extract (Persea americana Mill.) Positively contain chemical compounds of alkaloids and flavonoids. Comparison of the amount of ethyl acetate: $n$-hexan solvent affects the amount of yield.

Keywords: avocado seeds, maceration method, solvent mix.

\section{PENDAHULUAN}

Menurut Badan Penelitian dan Pengembangan Kesehatan Kementerian Kesehatan RI menyatakan bahwa hasil riset kesehatan dasar yang memanfaatkan Pelayanan Kesehatan Tradisional (Yankestrad) di masyarakat masih tinggi. Proporsi rumah tangga yang pernah memanfaatkan Yankestrad dalam waktu satu tahun menunjukkan angka nasional 30,4\% dan khusus untuk Yankestrad ramuan adalah $49,0 \%$. Salah satu tanaman yang dapat dijadikan bahan pengobatan tradisional yaitu alpukat yang dapat mengatasi penyakit seperti monorrhagia, hipertensi, sakit perut, bronkitis, diare dan diabetes ${ }^{2}$

Tanaman alpukat (Persea americana Mill.) adalah tanaman buah yang termasuk kedalam keluarga Lauraceae. Kandungan gizi yang terdapat pada daging buah alpukat, diantaranya: vitamin $A, B, C$, dan $E$ serta $\beta$ karoten dalam jumlah yang tinggi sedangkan bagian daun digunakan untuk ramuan obat penyakit hipertensi dan ginjal ${ }^{3}$. Pada tahun 2017 data statistik produksi holtikultura produksi alpukat di Indonesia mencapai $3,631,476$ kuintal. Dari data tersebut, produksi alpukat di Indonesia terus meningkat setiap tahunnya, seiring dengan meningkatnya produksi alpukat, maka limbah biji alpukat yang dihasilkan juga meningkat. Limbah biji alpukat dianggap tidak bermanfaat sehingga dibuang begitu saja menjadi limbah yang belum digunakan secara ekonomis ${ }^{4}$.

Biji alpukat memiliki beberapa bagian, yaitu: $15 \%$ perikarp, $20 \%$ endocarp dan $65 \%$ mesokarp ${ }^{4}$ Pada beberapa penelitian membuktikan bahwa ekstrak etanol biji alpukat (Persea americana Mill.) mengandung metabolit sekunder diantaranya adalah alkaloid, tanin, polifenol, flavonoid saponin, triterpenoid, kuinon, monoterpenoid dan seskuiterpenoid ${ }^{5}$ dan rendemen yang dihasilkan dari ekstrak etanol biji alpukat menggunakan metode ekstraksi maserasi yaitu sebesar $13,09 \%{ }^{6}$. Selain golongan senyawa kimia yang disebutkan diatas, biji alpukat memiliki kandungan lain yaitu lemak. Kandungan lemak yang dimiliki sebesar 1 $1,5 \%$, dengan komposisi: asam strearat sebesar 1,45\%; asam palmitat sebesar $12,87 \%$; asam oleat sebesar $57,44 \%$; asam palmitoleat sebesar $3,86 \%$; asam linoleat sebesar 6,3- $11,3 \%$ dan asam miristat sebesar $0,06 \%{ }^{6}$. Biji alpukat mempunyai indikasi sebagai antioksidan².

Berdasarkan pernyataan diatas, pada penelitian ini akan dilakukan penelitian mengenai pengaruh perbedaan variasi pelarut campur etil asetat dan n-heksan terhadap persentase rendemen dan kandungan golongan senyawa kimia biji alpukat (Persea americana Mill.) menggunakan metode ekstraksi dingin yaitu maserasi, guna melihat banyaknya persentase bobot rendemen ekstrak etil asetat dan $\mathrm{n}$-heksan serta golongan senyawa kimia pada biji alpukat yang terserap dalam pelarut.

\section{METODE}

Jenis penelitian ini yaitu eksperimental laboratorium dengan metode ekstraksi maserasi. Sampel yang digunakan adalah biji alpukat (Persea americana Mill.) dari perkebunan buah alpukat di Kampung Ganimukti RT/RW 02/03, Desa Santanamekar Cisayong, Tasikmalaya.

Data yang digunakan adalah data deskriptif yang ditampilkan dalam bentuk tabel hasil pengamatan persentase rendemen dan golongan senyawa kimia ekstrak biji alpukat (Persea americana Mill.). 


\section{Prosedur pembuatan}

1. Penyiapan Bahan Penelitian

$$
\text { Bahan yang akan }
$$

digunakan adalah simplisia biji alpukat yang diperoleh dari perkebunan alpukat di Kampung Ganimukti RT/RW 02/03 Desa Santanamekar Cisayong Tasikmalaya dan dilakukan determinasi di Jurusan Biologi Universitas Siliwangi Tasikmalaya. Determinasi tanaman dilakukan untuk menetapkan keaslian dari tanaman yang akan digunakan dalam penelitian. Biji dari buah alpukat yang telah matang dibersihkan dan dicuci dengan air mengalir sampai bersih lalu tiriskan dan dilakukan penyortiran. Biji alpukat dirajang kecil-kecil 2-3 $\mathrm{cm}$ untuk memudahkan proses pengeringan. Proses pengeringan dilakukan dibawah sinar matahari langsung sampai kering selama 7 hari, simplisia kering dibersihkan kembali dari kotoran yang mungkin tercemar pada saat pengeringan (sortasi kering). Selanjutnya simplisia kering dihaluskan menggunakan blender sampai menjadi simplisia serbuk dan diayak menggunakan ayakan mesh 60 sehingga diperoleh simplisia serbuk dan disimpan dalam wadah bersih tertutup rapat $^{7}$.

2. Pembuatan Variasi Konsentrasi Pelarut

Pelarut yang akan digunakan adalah etil asetat dan n-heksan dengan perbandingan 1:9; 3:7; 5:5; 7:3 dan 9:1.

3. Pembuatan Ekstrak
Ekstrak biji alpukat
diperoleh dengan metode maserasi, yaitu biji alpukat yang telah dibuat simplisia ditimbang sebanyak 10 gram dimasukkan kedalam gelas kimia (seluruh sisi gelas kimia dibungkus dengan aluminium foil) lalu ditambahkan campuran pelarut (etil asetat dan n-hexan dengan perbandingan $1: 9 ; 3: 7 ; 5: 5 ; 7: 3$ dan 9:1) sebanyak $100 \mathrm{ml}$. Metode maserasi merupakan metode yang aman karena metabolit sekunder yang tidak tahan pemanasan tidak akan rusak dengan metode ini. Proses ekstraksi dilakukan selama tiga kali 24 jam pada suhu kamar (20$25^{\circ} \mathrm{C}$ ) dengan pengadukan berulang tiap 3 jam sekali dalam 9 jam pertama. Ekstrak cair disaring dengan kertas saring, selanjutnya filtrat diuapkan dengan waterbath pada suhu $50^{\circ} \mathrm{C}$ sampai bobot konstan ${ }^{11}$.

4. Penapisan Fitokimia

a. Uji alkaloid

Pengujian alkaloid dilakukan dengan penambahan ammonia untuk membasakan, kemudian ditambahkan kloroform. Selanjutnya asam klorida $2 \mathrm{~N}$ ditambahkan kedalamnya, campuran dikocok kuat-kuat hingga terdapat dua lapisan. Lapisan asam dipipet, kemudian dibagi atas tiga bagian. Bagian pertama ditambahkan pereaksi Mayer, bila terjadi kekeruhan atau endapan dalam sampel kemungkinan terkandung alakaloid. Bagin kedua ditambahkan pereaksi Dragendorff, bila teradi kekeruhan atau endapan berwarna jingga kuning, berarti terkandung 
b. Uji Flavonoid

\begin{abstract}
alkaloid $^{8}$. Bagian ketiga ditambahkan pereaksi Bouchardat, bila terjadi endapan hitam-coklat terkandung alkaloid.
\end{abstract}

Sampel ditambahkan serbuk $\mathrm{Mg}$ dan $1 \mathrm{~mL} \mathrm{HCl}$ pekat. Selanjutnya ditambahkan amil alkohol dikocok dengan kuat. Adanya senyawa flavonoid menyebabkan filtrat berwarna merah, kuning, atau jingga dalam amil alkohol ${ }^{9}$.

c. Uji Saponin

Pengujian saponin dilakukan dengan menambahkan air ke dalam sampel, kemudian kocok dengan kuat selama sepuluh menit. Pembentukan busa sekurang-kurangnya setinggi $1 \mathrm{~cm}$ dan bertahan selama beberapa menit dan tidak akan hilang dengan penambahan $\mathrm{HCl}$ menunjukkan adanya saponin ${ }^{9}$.

d. Uji Tanin dan Polifenol

Senyawa tanin ditunjukkan dengan adanya endapan berwarna putih bila ditambahkan gelatin $1 \%$ kedalam sampel. Sedangkan kandungan polifenol alam ditunjukkan dengan adanya warna biru tua hingga hitam pada penambahan $\mathrm{FeCl}_{3}{ }^{9}$.

e. Uji Steroid dan Triterpenoid

Sampel diekstrak masingmasing ditambahakan eter, filtrat kemudian diuapkan dalam cawan penguap hingga kering. Kedalam diltrat ditambahkan pereaksi Libermann Burchard. Terjadinya warna ungu menunjukkan senyawa triterpenoid, sedangkan warna hijau biru menunjukkan adanya senyawa steroid ${ }^{8}$.

\section{Perhitungan Rendemen Ekstrak}

$\begin{array}{lr}\begin{array}{r}\text { Ekstrak biji } \\ \text { ditimbangat yang }\end{array} \\ \begin{array}{l}\text { delahasukkan } \\ \text { kedalam cawan } \\ \text { Selanjutnya, }\end{array} & \text { dipekatkan }\end{array}$ menggunakan waterbath dan dilakukan penimbangan hingga diperoleh bobot tetap ekstrak (perbedaan dua kali penimbangan berturut-turut setelah dikeringkan selama 1 jam tidak lebih dari $0,25 \%$ ). Ekstrak disimpan didalam desikator ${ }^{10}$.

Rendemen yang diperoleh dihitung menggunakan presentase bobot $(\mathrm{b} / \mathrm{b})$ antara rendemen dengan bobot serbuk simplisia yang digunakan dengan penimbangan. Perhitungan dilakukan untuk mengetahui presentase ekstrak yang dihasilkan dari setiap gram serbuk kering dengan metode ekstraksi yang dipilih ${ }^{11}$.

\section{HASIL}

\section{A. Determinasi Tanaman Biji Alpukat (Persea americana Mill.)}

Biji alpukat didapatkan dari perkebunan buah alpukat di Kampung Ganimukti, RT/RW 02/03, Desa Santanamekar Cisayong, Tasikmalaya.

\section{B. Ekstraksi Simplisia Biji Alpukat (Persea americana Mill.)}

Biji alpukat sebelum dilakukan proses ekstraksi, terlebih dahulu melalui proses pengeringan dengan metode dibawah sinar matahari langsung sampai kering selama 7 hari ${ }^{12}$.

\section{Perhitungan Rendemen}

Maserasi dilakukan sebanyak dua kali (duplo) dengan perlakuan yang sama terhadap simplisia biji alpukat. Perlakuan duplo bertujuan untuk meningkatkan ketepatan 
percobaan pada hasil rendemen. Adapun hasil rendemen ekstrak kental dari 10 gram biji alpukat dalam dua kali percobaan dapat dilihat pada Tabel 1.

Tabel 1. Hasil Rendemen Biji Alpukat

\begin{tabular}{cccc}
\hline $\begin{array}{c}\text { Variasi } \\
\text { Pelarut } \\
\text { etil } \\
\text { asetat : } \\
\begin{array}{c}\text { n- } \\
\text { heksan }\end{array}\end{array}$ & \begin{tabular}{c} 
Perlakuan \\
\cline { 2 - 4 }
\end{tabular} & Perlakuan 2 & $\begin{array}{c}\text { Rata-rata } \pm \text { Standar } \\
\text { Deviasi }\end{array}$ \\
\hline $1: 9$ & $0,232 \%$ & $1,376 \%$ & $0,804 \% \pm 0,809 \%$ \\
$3: 7$ & $0,997 \%$ & $1,891 \%$ & $1,444 \% \pm 0,632 \%$ \\
$5: 5$ & $1,95 \%$ & $2,934 \%$ & $2,442 \% \pm 0,696 \%$ \\
$7: 3$ & $3,434 \%$ & $3,766 \%$ & $3,600 \% \pm 0,235 \%$ \\
$9: 1$ & $6,771 \%$ & $5,762 \%$ & $6,267 \% \pm 0,713 \%$ \\
\hline
\end{tabular}

\section{Penapisan Fitokimia}

Penapisan fitokimia bertujuan untuk mengetahui komponen senyawa kimia yang terdapat pada tumbuhan. Penapisan fitokimia dilakukan sebanyak dua kali dengan perlakuan yang sama terhadap rendemen perlakuan pertama dan kedua.

Tabel 2. Hasil Penapisan Fitokimia

\begin{tabular}{|c|c|c|c|c|c|c|}
\hline \multirow{2}{*}{ Identifikasi } & \multicolumn{5}{|c|}{$\begin{array}{c}\text { Variasi Pelarut } \\
\text { Etil Asetat : n-heksan }\end{array}$} & \multirow{2}{*}{ Keterangan } \\
\hline & $1: 9$ & $3: 7$ & $5: 5$ & $7: 3$ & $9: 1$ & \\
\hline $\begin{array}{l}\text { Alkaloid } \\
\text { - Mayer } \\
\text { - Dragendorff } \\
\text { - Bouchardat }\end{array}$ & $\begin{array}{l}- \\
+ \\
+\end{array}$ & $\begin{array}{l}- \\
+ \\
+\end{array}$ & $\begin{array}{l}- \\
+ \\
+\end{array}$ & $\begin{array}{l}- \\
+ \\
+\end{array}$ & $\begin{array}{l}- \\
+ \\
+\end{array}$ & $\begin{array}{l}\text { Tidak terbentuk } \\
\text { endapan } \\
\text { Terbentuk endapan } \\
\text { jingga } \\
\text { Terbentuk endapan } \\
\text { hitam }\end{array}$ \\
\hline
\end{tabular}

\begin{tabular}{|c|c|c|c|c|c|c|}
\hline Flavonoid & + & + & + & + & + & $\begin{array}{l}\text { Terjadi perubahan } \\
\text { warna merah }\end{array}$ \\
\hline Saponin & - & - & - & - & - & Tidak terbentuk busa \\
\hline Tanin & - & - & - & - & - & Tidak terjadi endapan \\
\hline Polifenol & - & - & - & - & - & $\begin{array}{l}\text { Tidak terjadi } \\
\text { perubahan warna }\end{array}$ \\
\hline Steroid & - & - & - & - & - & $\begin{array}{l}\text { Terjadi perubahan } \\
\text { warna hitam }\end{array}$ \\
\hline Triterpenoid & - & - & - & - & - & $\begin{array}{l}\text { Terjadi perubahan } \\
\text { warna hitam }\end{array}$ \\
\hline
\end{tabular}

\section{PEMBAHASAN}

A. Determinasi Tanaman Biji Alpukat (Persea americana Mill.)

Determinasi tanaman

dilakukan untuk menetapkan keaslian dari tanaman yang digunakan dalam penelitian. Berdasarkan hasil determinasi tanaman alpukat yang digunakan memiliki keaslian dan kebenaran.

\section{B. Ekstraksi Simplisia Biji Alpukat (Persea americana Mill.)}

Metode pengeringan yang dilakukan merupakan cara yang paling mudah untuk mengetahui secara langsung tanaman yang dijemur sudah kering dan cocok untuk tanaman yang relatif keras seperti biji alpukat. Selanjutnya, diayak dengan mesh no. 60 yang berguna untuk mendapatkan hasil rendemen dan menarik senyawa golongan kimia secara maksimal. Mesh no. 60 merupakan kategori serbuk halus, karena dalam penelitian ini akan dilakukan proses ekstraksi maserasi sehingga ketika serbuk yang digunakan halus akan lebih besar luas permukaan yang dihasilkan dan interaksi antar pelarut akan lebih banyak. Setelah diperoleh serbuk simplisia berwarna merah kecoklatan, ekstraksi biji alpukat yang dilakukan menggunakan metode ekstraksi dingin, yaitu maserasi. Penggunaan metode maserasi merupakan metode yang sederhana, biaya operasional relatif rendah dan dapat menghindari rusaknya senyawa-senyawa metabolit sekunder yang bersifat termolabil $^{12}$. Metode ekstraksi maserasi merupakan metode 
yang aman dibanding metode lainnya, karena metode ekstraksi dingin lainnya memerlukan pelarut yang lebih banyak dan metode ektraksi panas kurang aman terhadap metabolit sekunder yang tidak tahan terhadap panas serta pada proses maserasi sangat menguntungkan dalam ekstraksi senyawa bahan alam karena dengan perendaman sampel tumbuhan akan terjadi pemecahan dinding dan membran sel akibat perbedaan tekanan antara didalam dan diluar sel, sehingga metabolit sekunder yang ada dalam sitoplasma akan terlarut dalam pelarut organik dan ekstraksi senyawa akan sempurna ${ }^{13}$. Prinsip dari metode maserasi ini adalah merendam bubuk simplisia dengan menggunakan pelarut etil asetat dan n-heksan pada temperatur ruang dan terlindungi dari cahaya. Ekstraksi dilakukan dengan menggunakan sampel biji alpukat yang sudah dibuat menjadi simplisia kering dan pelarut yang digunakan untuk perendaman ini yaitu etil asetat dan n-heksan. Simplisia biji alpukat sebanyak 10 gram direndam menggunakan pelarut etil asetat : n-heksan dengan variasi pelarut yang berbeda $1: 9 ; 3: 7 ; 5: 5 ; 7: 3 ; 9: 1$ sebanyak $100 \mathrm{ml}$, guna melihat pengaruh dari variasi pelarut tersebut terhadap rendemen dan golongan senyawa kimia dari ekstrak biji alpukat.

Maserasi

dilakukan

sebanyak tiga kali 24 jam dengan pengadukan berulang tiap 3 jam sekali dalam 9 jam pertama. Menurut Setyowati ${ }^{14}$ pada metode maserasi, dengan variasi pengadukan setiap satu jam menghasilkan rendemen lebih besar daripada metode maserasi dengan variasi pengadukan sesekali yang disebabkan kontak yang lebih sering terjadi antara sampel dan pelarut dengan adanya pengadukan yang kontinyu. Semakin banyak pengadukan maka semakin banyak desakan antara pelarut dengan sel sehingga semakin banyak senyawa organik yang terlarut.

Maserat yang didapat
berwarna jingga sampai
kecoklatan, kemudian diuapkan pelarutnya dengan menggunakan waterbath hingga didapat esktrak kental dan memiliki bobot konstan. Bobot konstan diperoleh dengan cara menimbang sampai berat maserat tidak mengalami perubahan angka selama tiga kali penimbangan dalam rentang waktu yang berbeda. Ekstrak yang didapat berwarna coklat, berbau khas biji alpukat, lengket, tidak dapat dituang dan memiliki bobot konstan.

\section{Perhitungan Rendemen}

Berdasarkan Tabel 1 dapat dilihat bahwa terdapat perbedaan hasil rendemen ekstrak biji alpukat dengan variasi pelarut yang berbeda. Hal ini membuktikan bahwa jenis pelarut yang digunakan berpengaruh terhadap rendemen. Etil asetat dan $\mathrm{n}$-heksan merupakan kedua pelarut yang memiliki tingkat kepolaran berbeda, dimana etil asetat merupakan jenis pelarut semi polar sedangkan n-heksan merupakan jenis pelarut nonpolar. Setiap tahapan ekstraksi yang dilakukan diharapkan dapat mengekstrak senyawa yang mempunyai kepolaran sesuai dengan kepolaran pelarut. Penggunaan kedua pelarut dipilih dengan tujuan agar mampu menarik senyawa berdasarkan tingkat kepolarannya. Etil asetat yang bersifat semi polar akan menarik senyawa semi polar dan mampu mengekstrak senyawa fenol, 
terpenoid, alkaloid, aglikon dan glikosida. Sedangkan untuk n-heksan bersifat nonpolar akan menarik senyawa nonpolar dan dapat mengekstrak senyawa kimia seperti lilin, lipid dan minyak yang mudah menguap ${ }^{15}$. Menurut Firdiyani $^{16}$ pelarut memiliki kemampuan yang berbeda-beda dalam mengambil senyawa bioaktif sampel.

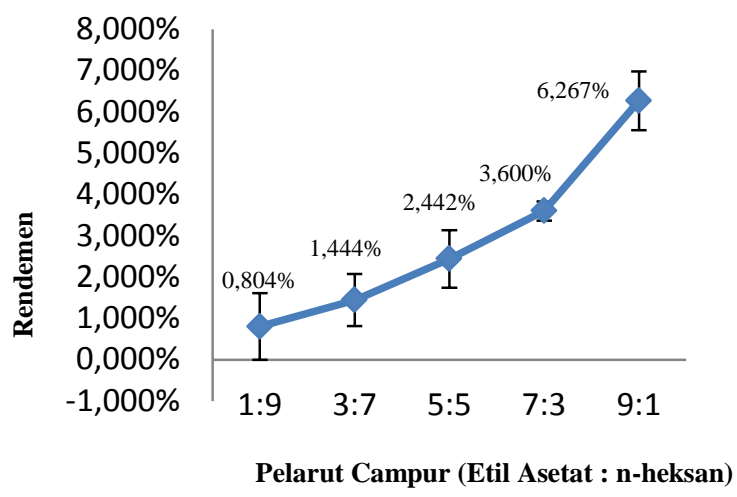

Gambar 1. Grafik Rendemen Ekstrak Biji Alpukat (Persea americana Mill.)

Proses ekstraksi dengan menggunakan variasi pelarut etil asetat : nheksan menghasilkan rendemen yang berbeda. Ekstrak dengan variasi pelarut 9:1 (etil asetat : n-heksan) memiliki rendemen paling tinggi dengan rata-rata yaitu $6,267 \%$ diikuti dengan variasi pelarut $7: 3$ yaitu $3,600 \%$; $5: 5$ yaitu $2,442 \% ; 3: 7$ yaitu $1,444 \%$ dan $1: 9$ yaitu $0,804 \%$ merupakan rendemen paling kecil.

Pada Tabel 2.2 dapat dilihat bahwa semakin besar volume etil asetat semakin besar konstanta dielektriknya, artinya perbandingan tersebut semakin naik tingkat kepolarannya. Menurut Cotton ${ }^{17}$ tetapan dielektrik merupakan penentu ukuran kepolaran suatu pelarut. Pada penelitian ini menunjukkan bahwa pada perlakuan etil asetat : n-heksan 9:1 dengan konstanta dielektrik 5,6 menghasilkan rendemen tertinggi. Sedangkan perlakuan 1:9 dengan konstanta dielektrik 2,4 menghasilkan rendemen paling rendah.

Tingginya hasil rendemen pada variasi pelarut 9:1 menunjukkan bahwa pelarut etil asetat mampu mengekstrak lebih banyak komponen bioaktif yang memiliki sifat kepolaran semi polar, artinya bahwa ekstrak biji alpukat kemungkinan lebih banyak mengandung senyawa yang bersifat semi polar dibanding dengan nonpolar. Selain itu, pengadukan pada saat ekstraksi metode maserasi menjadi salah satu pemicu untuk menghasilkan rendemen lebih besar karena kontak yang lebih sering terjadi antara sampel dan pelarut ${ }^{14}$.

\section{Penapisan Fitokimia}

Pada Tabel 2 hasil penapisan menunjukkan bahwa ekstrak biji alpukat (Persea americana Mill.) dengan variasi pelarut etil asetat : n-heksan yaitu $1: 9 ; 3: 7 ; 5: 5 ; 7: 3$ dan 9:1 positif mengandung senyawa metabolit sekunder flavonoid dan alkaloid dengan pereaksi dragendorff. Pada pengujian alkaloid (menggunakan mayer), saponin, tanin, polifenol, steroid dan triterpenoid menunjukkan hasil yang negatif setelah dilakukan pengujian sesuai indikator ditandai dengan tidak mengalami perubahan warna dan tidak terjadi endapan. Hasil dari penelitian ini sesuai dengan penelitian Benget ${ }^{18}$ yang menyatakan bahwa ekstrak etil asetat biji alpukat positif mengandung metabolit sekunder flavonoid dan alkaloid menggunakan pereaksi dragendorff, terkecuali saponin tidak menunjukkan hasil positif. Sedangkan ekstrak n-heksan biji alpukat positif mengandung alkaloid menggunakan pereaksi dragendorff.

Hasil penapisan fitokimia senyawa golongan alkaloid dalam ekstrak biji alpukat menggunakan pereaski mayer menunjukkan larutan berwarna bening dan tidak terdapat endapan, artinya alkaloid menggunakan pereaksi mayer negatif. Sedangkan identifikasi alkaloid menggunakan pereaksi 
dragendorff menunjukkan hasil positif yaitu menghasilkan warna jingga hingga coklat dan terbentuk endapan. Pereaksi dragendorff merupakan campuran dari bismut nitrat bereaksi dengan kalium idodida menghasilkan warna coklat bismut (III) iodida yang melarut dalam kalium idodida berlebih membentuk tetraiodobismutat. Endapan yang terbentuk merupakan kalium iodida $^{19}$.
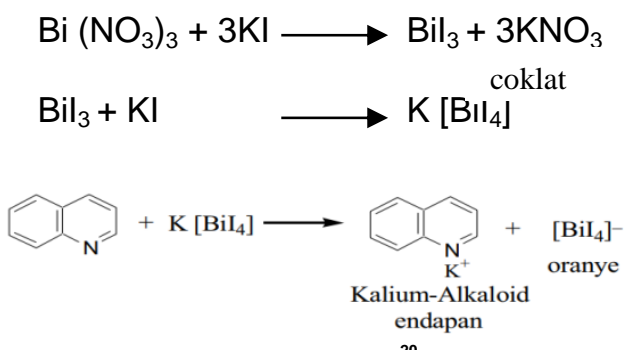

Gambar 2. Reaksi Uji Dragendorff ${ }^{20}$

Pada uji alkaloid dengan pereaksi bouchardart terbentuk endapan hitam-coklat, artinya ekstrak biji alpukat positif mengandung alkaloid. Bouchardat terdiri dari Iodium-Kalium Idodida yang bereaksi dengan nitrogen alkaloid membentuk garam kompleks berwarna yang sukar larut dalam air $^{21}$. Alkaloida positif jika terjadi endapan atau kekeruhan pada paling sedikit dua dari tiga percobaan di atas ${ }^{9}$.

Senyawa golongan flavonoid pada ekstrak biji alpukat menunjukkan hasil positif yang ditandai dengan perubahan warna merah setelah ditambahkan serbuk $\mathrm{Mg}$ dan $\mathrm{HCl}$ pekat serta amil alkohol. Warna ini terjadi karena terbentuknya garam flavilium $^{22}$. Senyawa golongan flavonoid bersifat polar sehingga dapat larut dalam pelarut polar dan semipolar. Kepolaran senyawa tersebut dikarenakan flavonoid merupakan senyawa polihidroksi (memiliki lebih dari satu gugus hidroksil) ${ }^{15}$.

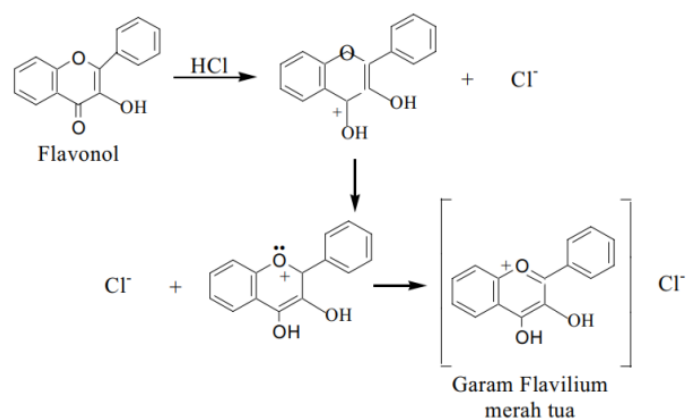

Gambar 3. Reaksi Uji Flavonoid (Marliana et al., 2005)

Hasil penapisan fitokimia senyawa golongan saponin dalam ekstrak biji alpukat menunjukkan negatif. Hal ini dilihat setelah dilakukan pengocokan tidak terbentuk busa, timbulnya busa yang dihasilkan menunjukkan adanya glikosida.

Tanin merupakan senyawa kimia yang tergolong dalam senyawa polifenol ${ }^{23}$. Senyawa golongan tanin dan polifenol pada ekstrak biji alpukat menunjukkan hasil negatif, hal ini terjadi karena biji alpukat tidak mengandung senyawa tanin sehingga tidak berikatan dengan gugus $\mathrm{Fe}^{+}$dan senyawa polifenol hanya dapat larut dalam senyawa polar. Etil asetat sebagai pelarut semi polar tidak mampu menarik senyawa yang terlalu polar maupun terlalu nonpolar ${ }^{24}$.

Senyawa golongan steroid dan triterpenoid pada ekstrak biji alpukat menunjukkan hasil negatif, dimana hasil yang didapat tidak terjadi perubahan warna. Hal ini karena pengujian didasarkan pada kemampuan senyawa steroid/triterpenoid untuk membentuk warna dengan asam 
sulfat pekat dalam pelarut asam asetat anhidrat ${ }^{25}$.

\section{SIMPULAN DAN SARAN}

Berdasarkan hasil dan pembahasan, dapat disimpulkan bahwa jenis pelarut dan proses pengadukan dalam proses ekstraksi metode maserasi sangat berpengaruh terhadap besarnya rendemen. Variasi pelarut etil asetat: n-heksan 1:9; 3:7 ; 5:5 ; 7:3 dan 9:1 berturut-turut dengan dua kali perlakuan yang sama, masing-masing menunjukkan hasil rendemen rata-rata berbeda yaitu 0,804\%; 1,444\%; 2,442\%; 3,600\% dan $6,267 \%$. Hasil penapisan fitokimia ekstrak biji alpukat (Persea americana Mill.) positif mengandung senyawa kimia golongan alkaloid dan flavonoid.

\section{Penulis}

merekomendasikan pelarut campur (etil asetat : n-heksan) 9:1 cocok digunakan untuk mengisolasi alkaloid dan flavonoid pada ekstrak biji alpukat dan perlu adanya penelitian lebih lanjut mengenai kuantitatif perbandingan senyawa kimia yang terdapat pada pelarut campur tesebut menggunakan pengujian Kromatografi Lapis Tipis (KLT) spesifik dan alat spektroskopi massa (MS).

\section{DAFTAR PUSTAKA}

${ }^{1}$ Badan Penelitian dan Pengembangan Kesehatan Kementerian Kesehatan RI, 2013, Riset Kesehatan Dasar (Riskesdas 2013), Badan Penelitian dan Pengembangan Kesehatan Kementerian Kesehatan Republik Indonesia, Jakarta, hal 47-48.

2 Ismawan, B., 2013. 100 Plus Herbal Indonesia Bukti Ilmiah \& Racikan,
PT Trubus Swadaya, Depok, hal 64-67.

3 Kemit, N., Widarta, I.W.R., dan Nocianitri, K.A, 2015, Pengaruh Jenis Pelarut dan Waktu Maserasiterhadap Kandungan Senyawa Flavonoid dan Aktivitas Antioksidan Ekstrak Daun Alpukat (Persea americana Mill.), Jurnal Jurusan IImu dan Teknologi Pangan, Fakultas Teknologi Pertanian Universitas Udayana, 130-141.

${ }^{4}$ Risyad, Atikah., Permadani, R.L., dan Siswarni, 2016, Ekstraksi Minyak dari Biji Alpukat (Persea americana Mill.) Menggunakan Pelarut NHeptana, Jurnal Teknik Kimia USU, Vol.5 No.1, 34-39.

5 Zuhrotun, A., 2007, Aktivitas Antidiabetes Ekstrak Etanol Biji Buah Alpukat (Persea americana Mill.) Bentuk Bulat, Karya IImiah, Fakultas Farmasi, Universitas Padjajaran, Jatinangor.

${ }^{6}$ Abubakar, A.N.F., 2016, Triterpenoid Biji Alpukat (Persea americana Mill.) dan Aktivitas Sitotoksiknya Terhadap Sel Kanker Payudara MCF-7 dan Hati HepG2, Tesis, Sekolah Pascasarjana Institut Pertanian Bogor.

7 Pratama, R.N., Widarta, I.W.R., dan Darmayanti, $\quad$ L.P.T., 2017 , Pengaruh Jenis Pelarut dan Waktu Ekstraksi dengan Metode Soxhletasi terhadap Aktivitas Antioksidan Minyak Biji Alpukat (Persea americana Mill.), Jurnal Media IImiah Teknologi Pangan, Vol.4 No.2, 85-93. 
${ }^{8}$ Farnsworth, N.R., 1966, Biological and Phytochemical Screening of Plants, Journal of Pharmaceutical Science, Vol.55 No.3, 225-276

9 DepKes R.I., 1995, Materia Medika Indonesia, Jilid VI, Departemen Kesehatan Republik Indonesia, Jakarta., hal 326-337.

10 Alphayovita, A.R., 2013, Pengaruh Waktu Pemberian Ekstrak Etanol Biji Persea americana Mill. Secara Akut Terhadap Kadar Kreatinin dan Gambaran Histologis Ginjal Tikus Terinduksi Karbon Tetraklorida, Skripsi, Fakultas Farmasi Universitas Sanata Dharma Yogyakarta.

${ }^{11}$ DepKes R.I., 2000, Parameter Standar Umum Ekstrak Tumbuhan Obat, Direktorat Jendral Pengawasan Obat dan Makanan, Jakarta, hal 731.

12 Savitri, Irena., Suhendra, Lutfi., dan Wartini, N.M, 2017, Pengaruh Jenis pelarut Pada Metode Maserasi Terhadap Karakteristik Ekstrak Sargassum polycystum, Jurnal Rekayasa dan Manajemen Agroindustri, Vol.5 No.3, 93-101.

13 Wullur, A.C., Schaduw, J., dan Wardhani, A.N.K, 2012, Identifikasi Alkaloid Pada Daun Sirsak (Annona muricata L.), Karya IImiah, Jurusan Farmasi Politeknik Kesehatan Kemenkes Manado, hal 54-56.

${ }^{14}$ Setyowati, W.A.E., dan Damayanti, D.R, 2014, Pengaruh Metode Ekstraksi Terhadap Aktivitas Antioksidan Kulit Buah Durian (Durio zibethinus Murr.) Varietas Petruk, Jurnal, Program Studi Kimia PMIPA FKIP, UNS Surakarta, 19
19

Asmara, A.P., 2017, Uji fitokimia Senyawa Metabolit Sekunder Dalam Ekstrak Metanol Bunga Turi Merah (Sesbania grandiflora L. Pers), Jurnal, Program Studi Kimia, Fakultas Sains dan Teknologi, Universitas Islam negeri Ar-Raniry, vol 5, 48-59.

18 Benget, V.V., Sidharta, B.B.R., dan Pranata, F.S., 2016, Uji Aktivitas Antibakteri Ekstrak Biji Alpukat (Persea americana Mill.) Terhadap Bacillus cereus dan Vibrio cholerae dengan Variasi Pengekstrak, Jurnal, Universitas Atma Jaya Yogyakarta Fakultas Teknobiologi, hal 1-13.

${ }^{15}$ Harborne, J.B., 1987, Metode Fitokimia Penuntun Cara Modern Menganalisis Tumbuhan Edisi II, Diterjemahkan oleh Kosasih Padmawinata dan Imam Sudiro, Bandung, ITB.

${ }^{16}$ Firdiyani, Fiya., Agustini, T.W., Ma'ruf, W.F., 2015, Ekstraksi Senyawa Bioaktif Sebagai Antioksidan Alami Sprulina platensis Segar dengan Pelarut yang Berbeda, Jurnal, JPHPI, Vol.18 No.1, 28-31.

17 Cotton, F. Albert, dan G. Wilkinson, 2006, Kimia Anorganik Dasar. UI Press, Universitas Indonesia.

18 Benget, V.V., Sidharta, B.B.R., dan Pranata, F.S., 2016, Uji Aktivitas Antibakteri Ekstrak Biji Alpukat (Persea americana Mill.) Terhadap Bacillus cereus dan Vibrio cholerae dengan Variasi Pengekstrak, Jurnal, Universitas Atma Jaya Yogyakarta Fakultas Teknobiologi, hal 1-13. 
19 Asmara, A.P., 2017, Uji fitokimia Senyawa Metabolit Sekunder Dalam Ekstrak Metanol Bunga Turi Merah (Sesbania grandiflora L. Pers), Jurnal, Program Studi Kimia, Fakultas Sains dan Teknologi, Universitas Islam negeri Ar-Raniry, vol 5, 48-59.

${ }^{20}$ Marliana, S., Suryanti, Suyono., 2005, Skrining Fitokimia dan Analisis Kromatografi Lapis Tipis Komponen Kimia Buah Labu Siam (Sechium edule Jacq. Swartz.) dalam Ekstrak Etanol, Jurnal, Jurusan Kimia FMIPA, Universitas Sebelas Maret, Vol.3 No.1, 26-31.

${ }^{21}$ Kakuda, Y., dan Kamel, B.S., 1992, Fatty Acids in Fruits and Fruits Products, Marcel Dekker Inc, New York.

${ }^{22}$ Marlinda, M., Sangi, M.S., dan Wuntu, A.D., 2012, Analisis Senyawa Metabolit Sekunder dan Uji Toksisitas Ekstrak Etanol Biji Buah Alpukat (Persea americana Mill.), Jurnal Mipa Unsrat Online 1 (1): 2428.

${ }^{23}$ Deaville, E.R., D.I. Givens., I. Mueler Harvey, 2010, Chesnut and Mimosa Tannin Silages: Effect In Sheep Differ for Apparent Digestibilty, Nitrogen Utilitation and Losses, Anim. Feed Sci. Technol, 157:129138

24

Putri, W.S., Wardianti, N.K., dan Larasanty, L.P.F, 2013, Skrining Fitokimia Ekstrak Etil Asetat Kulit Buah Manggis (Garcinia mangostana L.), Jurnal IImiah, Jurusan Farmasi Fakultas Matematika Dan IImu Pengetahuan Alam Universitas Udayana, 56-60.
${ }^{25}$ Pratama, R.N., Widarta, I.W.R., dan Darmayanti, L.P.T., 2017, Pengaruh Jenis Pelarut dan Waktu Ekstraksi dengan Metode Soxhletasi terhadap Aktivitas Antioksidan Minyak Biji Alpukat (Persea americana Mill.), Jurnal Media IImiah Teknologi Pangan, Vol.4 No.2, 85-93. 